\title{
Utilization of Water Hyacinth and Dolomite Fertilazer in Chrysanthemum Cut Flower
}

\author{
I Gusti Made Arjana ${ }^{*}$, I Nyoman Rudianta ${ }^{2}$ and I Ketut Sunadra ${ }^{3}$ \\ Universitas Warmadewa, Denpasar-Bali, Indonesia \\ \{igmarjana@gmail.com¹, inyomanrudianta@gmail.com²,iketutsunadra@gmail.com³
}

\begin{abstract}
The study, entitled utilization of water hyacinth and dolomite fertilizer in chrysanthemum cultivation, aims to determine the dosage of water hyacinth and dolomite fertilizer and their interactions with chrysanthemum cultivation. The research method used a randomized block design with a two-factor factorial pattern, namely: three levels of water hyacinth: 1.5 tonnes ha-1, 3.0 tonnes ha-1, and 3.5 tonnes ha-1, and three levels of dolomite fertilizer: $150 \mathrm{~kg}$ ha- $1,300 \mathrm{~kg}$ ha-1, and $450 \mathrm{~kg}$ ha- 1 . The interaction between water hyacinth dose and dolomite fertilizer had no significant effect on all variables. Treatment of water hyacinth dosage 3.5 ton ha-1 resulted in the highest flower stalk length and fresh weight of $155.30 \mathrm{~cm}$ and $74.52 \mathrm{~g}$, the results increased $9.88 \%$ and $25.93 \%$ when compared to the lowest treatment. Dolomit fertilizer dose of $450 \mathrm{~kg}$ ha- 1 yielded the highest flower stalk length and fresh weight of $150.03 \mathrm{~cm}$ and $67.23 \mathrm{~g}$, the yield increased by $4.21 \%$ and $7.47 \%$ when compared to the lowest treatment.
\end{abstract}

Keywords: chrysanthemum; dolomite; water hyacinth

\section{Introduction}

Chrysanthemum (Dendranthema grandiflora, Tzvelev) or known as chrysanthemum flowers, is a commodity that has a high economic value so that it has the potential to be developed commercially as a basic component in agribusiness, both as cut flowers, potted ornamental plants and medicinal plants [1] . Chrysanthemum is one of the leading floricultural products developed in several centers, especially to meet the domestic market. The use of chrysanthemum in each flower arrangement is very dominant, reaching $30-65 \%$. It is quite prospective to continue to develop both the quality, quantity and development of the chrysanthemum business industry. Chrysanthemum cultivation, which was originally concentrated in Java, has now spread widely to Bali.

Chrysanthemum flower production in Java and Bali has not been able to meet market demand because productivity is still low. Increased production needs to be continuously increased through both extensification and intensification. Currently, chrysanthemum planting in Bali was only concentrated in Buleleng and Tabanan districts, so it needs to be developed in other potential areas. Areas that have the potential not to be planted with ornamental plants are due to various considerations such as being far from the marketing center, lack of adequate infrastructure, limited knowledge of cultivation, harvesting and post-harvest handling. Increasing production through intensification often encounters problems, among others, regarding pests and diseases, spacing, controlling soil moisture with mulch, determining the optimum dosage of organic and inorganic fertilizers, post-harvest (sorting, grading and 
packaging) and management of the production system. These cultivation factors are the cause of low production and quality of chrysanthemum flowers which affect the selling price of chrysanthemums as cut flowers [2].

The problem faced by farmers is the determination of the type of soil amendment material that is not suitable for local cultivation conditions, which is the cause of the low production and quality of chrysanthemums which affects the selling price of chrysanthemums as cut flowers. In addition, there are currently limited organic materials needed to improve soil fertility in quantity and quality.

Based on the foregoing, a study was conducted on the use of water hyacinth and dolomite fertilizer for chrysanthemum cut flower cultivation to support the production and quality of chrysanthemum flowers in order to increase farmers' income.Dokumen Word ini dapat digunakan sebagai template untuk naskah yang akan dipublikasikan di proceeding. Ikuti format teks pada intruksi teks pada bagian format teks, tables, Figure, sitasi dan referensi.

\section{Methods}

The research is located in Pancasari Village, Sukasada District, Buleleng Regency, which is $60 \mathrm{~km}$ from Denpasar City, with an altitude of 1,247 meters above sea level and an average temperature of $17^{\circ} \mathrm{C}$ to $20^{\circ} \mathrm{C}$.

The research method used a factorial randomized block design in the field in a green house. In this study, two factors were used: first, the dose of water hyacinth consisting of three levels, respectively: 1.5 tonnes ha- $1,3.0$ tonnes ha- 1 , and 3.5 tonnes ha- 1 , and dolomite fertilizer dosage consisted of three levels, respectively: $150 \mathrm{~kg}$ ha- $1,300 \mathrm{~kg}$ ha-1, and $450 \mathrm{~kg}$ ha-1. The combined treatment was 9 repeated 3 times, so that 27 experimental plots were needed. With a $2 \times 2 \mathrm{~m}$ plot size, the distance between the plots was $30 \mathrm{~cm}$ and the distance between replicates was $50 \mathrm{~cm}$. The research materials used included: chrysanthemum cuttings (spray type) of the White Reagent variety, water hyacinth, dolomoit fertilizer, fungicide, insecticide, acaricide and organic fertilizer.

The implementation of the experiment includes: media preparation, cleaning, cultivating and leveling the land for cut chrysanthemum cultivation as well as providing a suitable plant root system for the production of cut flowers, regulating soil aeration to maintain air exchange in the soil and conforming to standard tillage procedures. Before the land is processed, the land is cleared of crop residues, the land is hoeed to a depth of $30 \mathrm{~cm}$, then leveling is carried out. Making the beds, after the soil is processed then the beds are $1 \mathrm{~m} \times 1 \mathrm{~m}$ in size, the distance between the beds is $30 \mathrm{~cm}$, while the distance between replicates is $50 \mathrm{~cm}$. Furthermore, fertilization is carried out according to the treatment and basic fertilizer.

Fertilization, fertilization is carried out in accordance with the treatment tried, and the application of inorganic fertilizers as basic fertilizers with the fertilization dose is carried out after the plants are about 2 weeks old with $1.5 \mathrm{~g} / \mathrm{m}^{2}$ of urea applied through watering or drip irrigation. Furthermore, the same dose was carried out at 4 and 6 weeks of age. The last follow-up fertilization was carried out when the plants were 8 weeks old using $1.5 \mathrm{~g} / \mathrm{m}^{2}$ urea and $6 \mathrm{~g} / \mathrm{m}^{2} \mathrm{SP} 36$. Planting is done in the afternoon with a spacing of $12.5 \mathrm{~cm} \times 12.5 \mathrm{~cm}$. Plant maintenance, watering is carried out with drip irrigation according to the conditions in the field, embroidery is done after the plants are a week old after planting, weeding is adjusted to the growth of pests that grow in the field, pest and disease control is adjusted to the type of 
plant disturbing organisms with pesticide concentrations in accordance with its function to control these plant pests. Observation of plant growth and development until harvest.

The variables observed in this study were: the maximum plant height $(\mathrm{cm})$ was observed at the age of two weeks after planting, the measurement was continued every week until the maximum height was reached. Flower stalk length $(\mathrm{cm})$ measurement before harvest, by measuring the length of the flower stalk from the ground level to the highest flower tip.

Stem diameter $(\mathrm{cm})$ by measuring the diameter of the stem with the calipers before harvest, by measuring the plant stems between the maximum height. Flower diameter $(\mathrm{cm})$ is measured using calipers from fully bloomed flowers. The weight of the flower stalk (g) is measured by weighing the flower stalk after cutting it with an electric balance. Economic flower fresh weight $(\mathrm{g})$. Measured by weighing the economic value fresh flowers along $80 \mathrm{~cm}$ after harvest with an electric scale.

Observation data were analyzed statistically using analysis of variance if a single treatment had a real or very real effect followed by the smallest real difference test at $5 \%$ level, and if there was a real or very real effect on the interaction, it was continued with multiple distance test from Duncan's level of 5\%

\section{Results and Discussion}

The significance of the results of the analysis of the variance of the effects of the treatment of fertazer water hyacinth and dolomite and their interactions on all observed variables in chrysanthemum plants is presented in Table 1 . The average effect of fertilazer water hyacinth and dolomite treatment on maximum plant height $(\mathrm{cm})$, flower stalk length $(\mathrm{cm})$, stem diameter $(\mathrm{cm})$, flower diameter $(\mathrm{cm})$, weight of flower stalks, and fresh weight of economic flowers $(\mathrm{g})$ are presented in Table 2.

Table 1. The significance of the results of the analysis of variance on the effect of water hyacinth and dolomite fertilizers on chrysanthemum cut flowers

\begin{tabular}{clccc}
\hline & \multicolumn{1}{c}{ Variable } & \begin{tabular}{c} 
Treatment \\
\cline { 3 - 5 } No
\end{tabular} & $\begin{array}{c}\text { Wyacinth } \\
\text { Dolomite } \\
\text { Fertilazer }\end{array}$ & $\begin{array}{c}\text { Water Hycinth } \\
\text { Dolomite } \\
\text { Fertilazer }\end{array}$ \\
\hline 1 & Maximum plant height $(\mathrm{cm})$ & $* *$ & $* *$ & $\mathrm{~ns}$ \\
2 & Flower stalk length $(\mathrm{cm})$ & $* *$ & $* *$ & $\mathrm{~ns}$ \\
3 & Stem diameter $(\mathrm{cm})$ & $* *$ & $* *$ & $\mathrm{~ns}$ \\
4 & Flower diameter $(\mathrm{cm})$ & $* *$ & $* *$ & $\mathrm{~ns}$ \\
5 & Flower stalk weight $(\mathrm{g})$ & $* *$ & $*$ & $\mathrm{~ns}$ \\
6 & Economic flower fresh & $* *$ & $*$ & \\
\hline & weight $(\mathrm{g})$ & &
\end{tabular}

The results of the analysis of variance showed that water hyacinth treatment had a very significant effect $(\mathrm{P}>0.01)$ on all observed variables, while dolomite fertilizer treatment had a very significant effect $(\mathrm{P}>0.01)$ on all observed variables, except for flower stalk weight and fresh weight. economic interest has a significant effect $(\mathrm{P}>0.05)$. The interaction between water hyacinth and dolomite fertilizer treatment did not have a significant effect on all observed variables on the growth and development of chrysanthemum plants. This was due to 
the absence of mutual influence between water hyacinth and dolomite fertilizer, and only their own influence from the two factors or only one factor influences Table 1.

The treatment of increasing the dose of water hyacinth from 1.5 tonnes ha-1, 3.0 tonnes ha-1, and 3.5 tonnes ha-1 provided the maximum development of plant height, flower stem length, stem diameter, flower diameter, flower stalk weight and the highest economic fresh weight of flowers. and significantly different from other treatment levels (Table 2). The highest average length of flower stalks was $155.30 \mathrm{~cm}$ and fresh weight of economic flowers of $74.52 \mathrm{~g}$ was found in the water hyacinth dose treatment of 3.5 tons ha- 1 and the lowest was in the treatment of 1.5 tons ha- 1 of $55.20 \mathrm{~g}$ and $139.96 \mathrm{~cm}$, respectively. the yield increase was $9.88 \%$ and $25.93 \%$ when compared to the lowest treatment.

Treatment of water hyacinth at a dose of 3.5 ton ha- 1 produced the highest average variable and was significantly different at each dose level tried (Table 2). Plant growth and development due to water hyacinth treatment at a dose of 3.5 tonnes ha- 1 was able to give a real response to chrysanthemum because water hyacinth as a water weed can be used as a nutrient supplier, and contains quite a lot of N, P, K and micro nutrients [3], similarly stated the results of research on the processing of organic water hyacinth into a growing medium to support organic agriculture [4].

Table 2. Average effect of water hyacinth and dolomite fertilizers treatment on all observed variables

\begin{tabular}{lcccccc}
\hline Treatment & $\begin{array}{c}\text { Maximum } \\
\text { plant } \\
\text { height }(\mathbf{c m})\end{array}$ & $\begin{array}{c}\text { Flower } \\
\text { stalk length } \\
(\mathbf{c m})\end{array}$ & $\begin{array}{c}\text { Stem } \\
\text { diameter } \\
(\mathbf{c m})\end{array}$ & $\begin{array}{c}\text { Flower } \\
\text { diameter } \\
(\mathbf{c m})\end{array}$ & $\begin{array}{c}\text { Flower } \\
\text { stalk } \\
\text { weight } \\
\mathbf{( g )}\end{array}$ & $\begin{array}{c}\text { Economic } \\
\text { flower } \\
\text { fresh } \\
\text { weight }(\mathbf{g})\end{array}$ \\
\hline Water Hyacinth & & & & & & \\
1.5 ton ha $^{-1}$ & $127.02 \mathrm{c}$ & $139.96 \mathrm{c}$ & $2.39 \mathrm{c}$ & $5.32 \mathrm{c}$ & $75.19 \mathrm{c}$ & $55.20 \mathrm{c}$ \\
3.0 ton ha $^{-1}$ & $133.99 \mathrm{~b}$ & $145.52 \mathrm{~b}$ & $2.48 \mathrm{~b}$ & $6.92 \mathrm{~b}$ & $77.88 \mathrm{~b}$ & $63.79 \mathrm{~b}$ \\
3.5 ton ha $^{-1}$ & $145.66 \mathrm{a}$ & $155.30 \mathrm{a}$ & $2.62 \mathrm{a}$ & $8.35 \mathrm{a}$ & $80.86 \mathrm{a}$ & $74.52 \mathrm{a}$ \\
\hline BNT $5 \%$ & 0.37 & 0.27 & 0.008 & 0.076 & 0.14 & 0.42 \\
\hline Dolomite & & & & & & \\
Fertilazer & & & & & & \\
$150 \mathrm{~kg} \mathrm{ha}^{-1}$ & $132.72 \mathrm{c}$ & $143.72 \mathrm{c}$ & $2.44 \mathrm{c}$ & $6.26 \mathrm{c}$ & $77.01 \mathrm{c}$ & $62.21 \mathrm{c}$ \\
$300 \mathrm{~kg} \mathrm{ha}^{-1}$ & $134.83 \mathrm{~b}$ & $147.02 \mathrm{~b}$ & $2.50 \mathrm{~b}$ & $6.78 \mathrm{~b}$ & $77.82 \mathrm{~b}$ & $64.08 \mathrm{~b}$ \\
$450 \mathrm{~kg} \mathrm{ha}^{-1}$ & $139.12 \mathrm{a}$ & $150.03 \mathrm{a}$ & $2.55 \mathrm{a}$ & $7.56 \mathrm{a}$ & $79.11 \mathrm{a}$ & $67.23 \mathrm{a}$ \\
\hline BNT $5 \%$ & 0.37 & 0.27 & 0.008 & 0.076 & 0.14 & 0.42 \\
\hline
\end{tabular}

Note: The numbers in the same column for each factor followed by the same letter are not significantly different in the LSD test at 5\% level.

Nitrogen is an important element in the formation of chlorophyll, protoplasm, protein, and nucleic acids. This element has an important role in the growth and development of all living tissues [5]. Phosphorus is an important component of compounds for energy transfer (ATP and other nucleoproteins), for genetic information systems (DNA and RNA), for cell membranes (phospholipids), and phosphoproteins [6]. Potassium serves to balance the anion loads and affects the uptake and transport of these anions. Potassium can also reduce the incidence of certain diseases. The role of calcium is as a binder between phospholipid molecules or between phospholipids and membrane-making proteins, causing the membrane to function normally in all cells. Calcium can also stimulate the activity of several enzymes, as well as inhibit enzyme activity [7). The chemical nature of water hyacinth in compost is to add nutrients to the soil gradually and produce nutrients that are useful for plants in the long term. 
Water hyacinth compost is resistant to acids and alkalis in the soil and also provides a food source for microbes [8].

The treatment of increasing doses of dolomite fertilazer from $150 \mathrm{~kg}$ ha-1, $300 \mathrm{~kg}$ ha- 1 , and $450 \mathrm{~kg}$ ha- 1 resulted in the development of the maximum plant height, flower stem length, stem diameter, flower diameter, flower stalk weight and the highest economic fresh weight of flowers, and significantly different from other dose levels (Table 2). The highest average length of flower stalks was $150.03 \mathrm{~cm}$ and fresh weight of economic flowers of $67.23 \mathrm{~g}$ was found in the treatment dose of $450 \mathrm{~kg}$ ha- 1 and the lowest was in the treatment of $150 \mathrm{~kg} \mathrm{ha}-1$ of $62.21 \mathrm{~g}$ and $143.72 \mathrm{~cm}$, respectively. amounted to $4.21 \%$ and $7.47 \%$ when compared to the lowest treatment.

The increase in plant growth and development for each variable observed in the treatment of dolomite fertilizer dose of $450 \mathrm{~kg}$ ha- 1 is because dolomite provides nutrients for plants, helps to change soil $\mathrm{pH}$ according to plant needs, can neutralize excessive saturation of substances that can be toxic to soil. and plants such as: $\mathrm{Al}, \mathrm{Fe}$, and $\mathrm{Cu}$, giving dolomite increases the content of $\mathrm{Ca}$ and $\mathrm{Mg}$, and improves the availability of $\mathrm{P}$, to increase soil $\mathrm{pH}$, reduce Al content or saturation, and increase soil effectiveness and efficiency against the nutrients in it, maintain availability nutrients in the soil. Giving dolomite makes soil structure and porosity better and helps soil microbiology and soil chemistry work properly so that the soil becomes loose, soil circulation is smooth. Dolomite also helps the distribution of phosphorus in plants and stimulates the formation of fats, carbohydrates and various other nutrients [9].Dolomite is also an ameliorant in acid soils as a neutralizer for $\mathrm{Al}$ and $\mathrm{Fe}$ so that the absorption of nutrients $\mathrm{N}, \mathrm{P}$ and $\mathrm{K}$ is better. Dolomite also plays a role as a soil repairer, because too frequent application of ammonium and calcium fertilizers can result in a deficiency of magnesium, giving dolomite is able to neutralize the acidic reaction caused by excessive fertilizer application [10]. It was also stated that dolomite is a relatively cheap and effective source of $\mathrm{Mg}$ nutrients to increase $\mathrm{Mg}$ nutrient content in the soil. A source of nutrient $\mathrm{Ca}$ which has an important role in stimulating oil palm rooting. Increase soil $\mathrm{pH}$ and neutralize Al poisoning in oil palm areas which are generally acidic. Dolomite application will improve soil fertility, increase the effectiveness of fertilization, and produce healthy plant growth with high productivity [11].

\section{Conclusions}

The interaction between water hyacinth treatment and dolomite fertilizer has no significant effect on all observed variables on the growth and development of chrysanthemum plants.

The treatment of water hyacinth had a very significant effect $(\mathrm{P}>0.01)$ on all observed variables. Treatment of water hyacinth at a dose of 3.5 ton ha-1 produced the highest average fresh weight of economic flowers of $74.52 \mathrm{~g}$, and the lowest was in the treatment of 1.5 ton ha-1 dose of $55.20 \mathrm{~g}$, an increase in yield of $25.93 \%$ when compared to the lowest treatment.

Dolomite fertilizer treatment has significant to very significant effect on all observed variables. Dolomite fertilizer dose treatment of $450 \mathrm{~kg}$ ha-1 produced the highest average fresh weight of economic interest of $67.23 \mathrm{~g}$ and the lowest was in the treatment of $150 \mathrm{~kg}$ ha1 of $62.21 \mathrm{~g}$, an increase in yield was $7.44 \%$ when compared to the lowest treatment.

Acknowledgments. Many thanks to the Warmadewa University Research Institute for the study of applied product research in 2010. As well as friends and students who have helped 
carry out this research.The heading should be treated as a 3rd level heading and should not be assigned a number.

\section{References}

[1] H. R. Rukmana, "Krisan," Yogyakarta: Kanisius, 1997

[2] Darti, "Tanaman dan Budidaya Tanaman Hias," Jakarta: PD. Mahkota, 1992

[3] S. Rahman, "Penerapan pertanian organik pemasyarakatan \& pengembangannya,". Yogyakarta: Kanisius, 2006

[4] E. H. Sittadewi, "Pengolahan Bahan Organik Eceng Gondok menjadi Media Tumbuh untuk Mendukung Pertanian Organik," Jurnal teknologi lingkungan, vol.8, no 3. pp. 229-234, 2007

[5] N. C. Brady, and R. R. Weil, "The Nature and Properties of Soils," New Jersey: Upper Saddle River, 2002

[6] F. P. Gardner, R. B. Pearce and R. L. Mitchell, "Fisiologi Tanaman Budidaya (Physiology of Crop Plants),". Jakarta: Ul-Press, 1991

[7] B. Lakitan, "Dasar-dasar Fisiologi Tumbuhan," Jakarta: PT Raja Grafindo Persada, 2011

[8] C. D. Ganesh, "Composting of water hyacinth using Saw dust/Rice straw as a bulking agent," International Journal Of Environmental Sciences, vol. 2, no. 3, 2012

[9] Kampus Tani. : Manfaat Pupuk Dolomit Untuk kesuburan tanah dan Tanaman.https://www.kampustani.com (2019)

[10]Lubis, Yuni. : Dolomit. https://www.Academi.edu (2019)

[11]Dolomit A100 Fertilazer, 2010. https://agrounited.wordpress.com/dolomit-a100fertilize. 